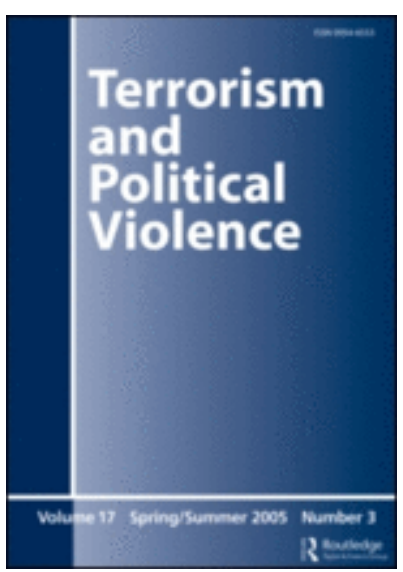

\title{
Loyalist Mobilisation and Cross-Border Violence in Rural Ulster, 1972-1974
}

\begin{tabular}{|r|l|}
\hline Journal: & Terrorism and Political Violence \\
\hline Manuscript ID & FTPV-2020-7142.R1 \\
\hline Manuscript Type: & Original Article \\
\hline Keywords: & loyalism, British Army, military intelligence, collusion, Northern Ireland \\
\hline
\end{tabular}

\section{SCHOLARONE ${ }^{m}$ Manuscripts}




\title{
Loyalist Mobilisation and Cross-Border Violence in Rural Ulster, 1972-1974
}

\section{Keywords}

Loyalism, British Army, military intelligence, collusion, Northern Ireland

\begin{abstract}
This article argues that, at a tactical level, loyalist terrorism in the Irish border region between 1972 and 1974 worked. Cross-border attacks including bombings in Irish towns and the targeting of IRA safe-houses prompted the Irish government to reinforce security along the border - a long-standing loyalist demand. The loyalist campaign prompted the IRA to embark on an effort to punish those who were believed to have passed information to loyalists, resulting in the killing in an Irish Protestant senator and widespread condemnation of the organisation in the Republic of Ireland. However, short-term gains were outweighed by a growing perception among Catholic nationalists that the British state tolerated or even colluded in such attacks, undermining the British Army's campaign to gain trust (and information) within the Catholic population of Northern Ireland. The article also contends that middle-class loyalists played an important role in mobilising and equipping loyalist paramilitary organisations. It concludes that the British Army showed an excessive tolerance of loyalists with political capital or ties to the security forces, despite evidence that such individuals were directly supporting the activities of loyalist paramilitaries.
\end{abstract}

\section{Loyalist Mobilisation, Elite Networks and Border Violence in Rural Ulster 1972-1974}

In January 1972, during the most violent period of Northern Ireland's Troubles, an Irish military officer wrote an intelligence report that suggested that the British Army was withdrawing from some western parts of the border between Northern Ireland and the Republic of Ireland. The Irish officer concluded that the British Army was "creating a DMZ [demilitarized zone] one mile from the border." On March 1 a Provisional Irish Republican Army (IRA) unit abducted Johnny Fletcher, a part-time soldier in the Ulster Defence Regiment (UDR) from his County Fermanagh border farm, before shooting him dead in a nearby field. A few days later UDR headquarters instructed a number of part-time soldiers to move out of the border area near where Johnny Fletcher was killed. ${ }^{2}$ In border areas with sizeable Protestant minorities fears of an imminent British withdrawal were particularly acute. John Taylor, a former Northern Ireland cabinet minister with responsibility for security at the Ministry of Home Affairs (1970-1972) warned that, if their political opponents were successful, "... the average Protestant small farmer and the worker would be squeezed out the same as happened in Eire [sic]" after the foundation of the Irish state in 1922. ${ }^{3}$ As a response, influential figures in mainstream Unionism, including former members of the Northern Irish government, came to support loyalist paramilitary activity as a desperate response to a deteriorating situation. ${ }^{4}$

This article poses three connected questions. First, why did rural cross-border loyalist activity suddenly escalate between 1972 and 1974? Second, did local political and business elites in rural areas direct and enable significant loyalist paramilitary activity, including through relationships with representatives of the state and through links to more working-class paramilitary groups? Third, did loyalist terrorism and political violence work? Anthony Craig ${ }^{5}$, Shaun McDaid ${ }^{6}$, Thomas Leahy ${ }^{7}$ and Patrick Mulroe ${ }^{8}$ have already noted a determined effort by both the Irish and the UK governments to deepen security cooperation in response to IRA violence. An increase in resources and intelligence-sharing led to more arrests, substantially degrading the IRA's operational capacity on both sides of the border. ${ }^{9}$ However, the conduct and effect of the loyalist border campaign has received less attention. 
The article responds to the call by Richard English for more empirical research on the "difficult question" of the efficacy of terrorism. ${ }^{10}$ Moreover, while significant attention has been paid to terrorism as practiced by active or would-be insurgents, much less study has been focused on terrorists who wish to suppress rather than bring about significant political change. ${ }^{11}$ The loyalist argument was that their own violation of the law was a temporary aberration or emergency that would end when unionist majority rule in Ulster was once again secure. As an Ulster loyalist on trial for murder during another period of violence in 1922 observed: "I, Sir, may have broken the law but it was to assist the Crown Forces in my own way." 12

In analysing the political impact of loyalist border violence from 1972-1974, this article draws upon English's definition of terrorism;

Terrorism involves heterogeneous violence used or threatened with a political aim; it can involve a variety of acts, of targets, and of actors; it possesses an important psychological dimension, producing terror or fear among a directly threatened group and also a wider implied audience in the hope of maximizing political communication and achievement; it embodies the exerting and implementing of power, and the attempted redressing of power-relations; it represents a subspecies of warfare, and as such it can form part of a wider campaign of violent and non-violent attempts at political leverage. ${ }^{13}$

The observation by English that terrorism may serve as one tool in a wider campaign of exerting political influence is instructive. The loyalist border campaign of 1972-1974 was not especially deadly, at least compared to that of the IRA. However, the impact of the wider mobilisation of loyalist paramilitary networks in rural areas was considerable, putting pressure on the security forces, including when it came to the question of infiltration.

There has been a notable neglect of the study of rural loyalism during the Troubles. In a recent book, Brian Hanley describes a number of loyalist attacks in the border areas. However, Hanley's work is concentrated on the impact of the Troubles in the Republic of Ireland, rather than the whole island. ${ }^{14}$ Meanwhile, Henry Patterson's work does not focus on loyalist bombings and assassinations in the rural, border region. Patterson's contribution is overwhelmingly concerned with republican violence and the British-Irish security relationship. ${ }^{15}$ Elsewhere, the activities of the loyalist 'Glenanne Gang' and the 'murder triangle' between east Tyrone, north and mid-Armagh have been widely covered. However, even here most of the leaders of loyalist paramilitary groups operating in this area lived in and operated around large towns like Portadown in County Armagh and Dungannon in County Tyrone. ${ }^{16} \mathrm{~A}$ focus on urban loyalist violence is of course understandable. The majority of loyalist attacks were planned and carried out in urban areas. ${ }^{17}$ Steve Bruce has described loyalism as being an entirely working class phenomenon, writing that, "working class unionists - loyalists, as they are more often known - were willing to go further than others and believed it both necessary and right to use violence (or at least prepare to be in a position to use violence) to defeat nationalism." 18 It is true, as Bruce and others such as James McAuley and Richard Reed have described, that the explosion of recruitment to loyalist groups in the early 1970s was concentrated in working-class urban areas. Such recruitment was commensurate with the spike of IRA violence between 1971 and 1973 and resentment over the introduction of direct rule and fears over power-sharing negotiations and a role for the Irish government in Northern Ireland's affairs. ${ }^{19}$ 
If applied too widely, the concept of collusion can suggest more uniformity than was the case, giving a picture of institutional coherence instead of confusion or even chaos and ineptitude. It also risks placing the structure of the state and institution above the individual agency or autonomy of the soldier or police officer, suggesting that atrocity or criminality were an automatic or a reflexive feature of the institution rather than the choice of an individual, or a small group of individuals. Deviance is normalised, instead of being put in its proper, exceptional context. ${ }^{24}$ This article suggests that, although acts that meet McGovern's definition of collusion did take place (and some are discussed here for the first time), individual agency at a junior level could be a critical if not determining factor in those events.

The following discussion of rural loyalism is broken down into two principal sections. First, in order to appreciate the political and social networks that sustained grass-roots loyalist activity, this article will particularly focus on the counties of Fermanagh and Down, which have been largely omitted from studies of loyalism during the Troubles. In the case of County Down the relatively forgotten paramilitary organization, DOW, is outlined, including its relationship with the state and the more working-class Ulster Defence Association (UDA) and the Ulster Volunteer Force (UVF). Unlike another military veterans' paramilitary group tolerated by the state, the Catholic Ex-Servicemen's Association (CESA), DOW had a large arsenal of weapons and acted as an armorer to other paramilitary organizations, including those from the town of Portadown who were operating in the West Ulster border area. ${ }^{25}$

Secondly, the article goes on to evaluate the effect of the overlooked cross-border loyalist border campaign that occurred on the County Fermanagh border with the Republic of Ireland between 1972 and 1974. It argues that this loyalist campaign was successful in its immediate, tactical objectives, eliminating IRA safe-houses and weapons. More importantly loyalist attacks also provoked an increase in the Irish security presence along the border (a longstanding loyalist demand) and an IRA counter-intelligence initiative with damaging results for the Republican movement. However, loyalist activity south of the border, including the 
murder of two teenagers, hardened suspicions about collusion with the state, inflicting longterm damage to the British government's aim of lowering tensions and winning trust in the border region.

The period under discussion is from the outset of 1972, the most violent year of the Troubles, to the IRA's killing of an Irish senator, Billy Fox on March 121974 - the same month that Conservative Party leader Ted Heath resigned as Britain's prime minister and a new Labour government took office. Finally, given the social fluidity of the border region, including an enduring $20^{\text {th }}$ century legacy of unionist-loyalist ties south of the border in Cavan, Donegal and Monaghan, nine-county Ulster is proposed as a more appropriate geographical area for a treatment and discussion of rural loyalism than merely six-county Northern Ireland.

'You are in a War Situation': Rural Loyalist Mobilisation and the State

In the spring of 1972, as the IRA came under increased pressure in urban areas, its leaders decided to shift the momentum of the armed campaign to the border region. The British Army had concentrated its operations in the cites and large towns; in the border counties the IRA had the operational space it needed to launch surprise attacks from the south against regular and part-time soldiers and police officers. ${ }^{26} 3^{\text {rd }}$ Infantry Brigade (3 Brigade), with its headquarters in Lurgan, had the task of securing approximately 250 miles of the border. However, its battalions were principally deployed to large towns such as Armagh, Portadown, Dungannon and Newry. ${ }^{27}$ In addition to its presence in urban areas, 3 Brigade did not have sufficient resources to police a border area that included hundreds of unapproved crossings. In July 1972, the most violent month of the Troubles, there were less than 250 regular soldiers in County Fermanagh, with responsibility for patrolling 135 miles of border in addition to other tasks in the county. Despite the constant cratering of roads along the border, which enraged much of the majority nationalist, Catholic population, IRA attacks on part-time UDR soldiers and the bombing of Protestant-owned businesses in border towns quickly escalated during the summer and autumn of $1972 .{ }^{28}$

Rising IRA violence along the border stirred a loyalist response. In October 1972 3,000 loyalists, including members of paramilitary groups such as the UDA, the UVF, the Loyalist Association of Workers (LAW) and the Ulster Special Constabulary Association (USCA) gathered beside the police station in the town of Enniskillen to hear accounts of recent loyalist cross-border raids into the Republic of Ireland. ${ }^{29}$ The UDA and DOW were closely associated with former Northern Irish Home Affairs minister William Craig's Vanguard movement - a militant organization which formed its own paramilitary unit, the Vanguard Service Corps. Leading Ulster Unionists in the border counties were also sympathetic to Vanguard and the broader loyalist paramilitary movement. In March 1972 the West Ulster Unionist Association expressed "strong and unanimous support for the Ulster Vanguard Movement." ${ }^{30}$ In the summer of that year, John Brooke, the Chairman of Fermanagh County Council and a former Ulster Unionist Party (UUP) government minister, claimed that all Unionists in west Ulster were now united with Vanguard. ${ }^{31}$ In a speech in the town of Enniskillen, Brooke's father and former prime minister of Northern Ireland, Viscount Brookeborough, recalled an earlier conflict (the Anglo-Irish War of 1919-1921) when he founded a paramilitary organization, Fermanagh Vigilance, before later taking command of the auxiliary police unit, the Ulster Special Constabulary (USC). While advising young loyalists to join the UDR and take the fight to the IRA, he also praised unnamed "other bodies" who he said were doing "good work". ${ }^{32}$ Other Ulster Unionist representatives were more explicit in their support for loyalist paramilitary operations in the Republic of Ireland. In the autumn of 1972 John Taylor thanked "... God for the imagination of the people who 
had the wisdom to form organizations like the LAW and the UDA ..." Taylor also stated that he supported the UDA going across the border and "rooting out" the IRA, arguing that loyalist cross-border bombings "have been an advantage to Northern Ireland security." 33 Vanguard leader Bill Craig also praised the UDA, claiming that loyalists had "no regrets" in hitting back at the Republic of Ireland. ${ }^{34}$

British government officials were also considering ways to respond to the escalating IRA border campaign. Garda sources had informed the British Army that it was difficult to secure convictions against leading IRA men; senior members of the Irish judiciary could be very sympathetic to the IRA. In March 1972 the Ministry of Defence (MOD) considered the option of covert, cross-border raids south of the border to target IRA Active Service Units (ASUs). ${ }^{35}$ Meanwhile, the British Army was increasingly concerned about the loyalties of the UDR and those of the Northern Irish police, the Royal Ulster Constabulary (RUC). In a memorandum sent to the commanding officers of battalions in the 3 Brigade area of operations (AO), Brigadier Peter Bush pointed out that, while countering loyalist violence was principally a RUC responsibility, there were a number of "serious weaknesses which cannot be ignored: a) Some lack the resolve to deal with extremist Protestants ...; b) some are intimidated by the extremists ... c) some are penetrated by the Protestant extremist organisations and many of them sympathise with militant Protestant aims; d) they are very short of high-grade CID officers and efficient administrators." Bush observed that the publication of the British government's white paper on power-sharing in Northern Ireland would mean a "difficult period when [RUC] loyalties are strained." ${ }^{36} \mathrm{He}$ also estimated that up to 300 UDR (approximately 10 per cent) of part-time soldiers in 3 Brigade's AO were members of militant Protestant organisations. 3 Brigade's commander predicted a scaling up of loyalist attacks along the border but he had few answers about how to respond to the coming campaign beyond a "weeding out" of paramilitary elements over time. ${ }^{37}$ In the summer of 1972 Bush sent a directive to all units serving under his command instructing them to "to avoid, to the greatest extent possible, confrontation with the Protestant community." It was clear to Bush that an over-stretched 3 Brigade could not cope with additional security duties such as a major confrontation with the UDA. ${ }^{38}$

Respected businessmen, farmers and former police officers played pivotal roles in establishing and running loyalist paramilitary units in rural Ulster. British military intelligence claimed that a key loyalist paramilitary organiser in Tyrone was a prominent businessman (later arrested on an explosives charge). ${ }^{39}$ In Fermanagh, Basil Anderson, a former RUC officer in Enniskillen who had also served in the Royal Air Force, worked to set up a coalition of paramilitary organisations under the banner of Ulster Vanguard. Anderson's Loyalist Defence Volunteers included leading UDA and USCA figures in the county. ${ }^{40}$ Former UDR soldier, George Farrell, who was convicted in relation to his role in a bomb attack in Pettigo on 28 September 1973 and claimed to be both a member of the UVF and the UDA, named five other loyalists at his trial who he claimed were involved in operations, including a well-known Fermanagh businessman..$^{41}$ Meanwhile, prominent serving UDR officer, such as Lieutenant Colonel George Saunderson, second-in-command of $4^{\text {th }}$ Battalion, UDR (County Fermanagh), was a leading member of the USCA which had morphed into a vigilante group with close ties to paramilitary organisations like the UDA. ${ }^{42}$

DOW has generally been overlooked in the historiography of the Troubles, possibly because the organisation did not claim any victims. DOW was led by Peter Brush, a septuagenarian former army officer who had served as a young lieutenant in the Rifle Brigade in Dublin and west Ulster during operations against the IRA in 1920 and 1921. Brush retired from the army 
in 1946 and returned to the family estate at Drumnabreeze, County Down, a few miles outside the town of Lurgan. He later served as a High Sheriff, Deputy and Vice Lord Lieutenant of County Down, entertaining the Queen and the royal family during their visits to Northern Ireland. He was also chairman of the County Down Territorial Army (TA) Association and Northern Ireland's representative to the Executive Committee of the TA. ${ }^{43}$ According to Brush, in 1971 he was approached by the grand master of the Orange Order in Down, who asked him to form a paramilitary organisation, one that would ensure that if the security situation in Northern Ireland deteriorated significantly, unionists in the county "would have a cadre of men ready to meet the unforeseen." 44 Through his former and existing army and police contacts in the county, he formed 'battalions', including one in North Down commanded by 'Colonel' Bill Hannigan. Hannigan lived in the coastal village of Donaghadee on the Ards Peninsula where he also served in the RUC Reserve. ${ }^{45} \mathrm{~A}$ former warrant officer in the Royal Irish Fusiliers, he was awarded the Military Medal for bravery in Aden. ${ }^{46}$ The intelligence officer for DOW, who lived near the village of Saintfield, served in a military intelligence role during the Cyprus Emergency of the $1950 \mathrm{~s}^{47}$

In April 1973 a British Army intelligence report noted that DOW had begun arms and explosives training. In August, military intelligence officers estimated that DOW's membership stood at somewhere between 1,000 and 1,800 members. The following month the Army suspected that DOW may have been behind a weapons factory that was discovered near Killinchy along with 241 partially or fully manufactured mortars, until then the largest arms find in Northern Ireland's history. ${ }^{48}$ Throughout this period of paramilitary activity, Brush maintained his position as president of the Ulster Unionist Association of South Down; Herbert Heslip, also a farmer and a leading figure in DOW, was a member of the Northern Ireland Assembly. ${ }^{49}$ Occasional meetings were held between the security forces and DOW to discuss the latter's intentions. Military intelligence officers recorded Bill Hannigan's "friendly" attitude, noting that he showed off his DOW lieutenant colonel's uniform, while simultaneously stressing "DOW's intention of cooperating with the Security Forces." 50

In intelligence reports compiled in the spring and summer of 1973, officers in 3 Brigade concluded that DOW posed no threat to security in Northern Ireland. ${ }^{51}$ Yet by December of that year 3 Brigade intelligence indicated that DOW had "joined the loyalist camp" and had "dispersed all their illegally held weapons". ${ }^{52}$ Despite mounting evidence that the organisation was working closely with the UDA and the UVF, the British government and the military largely ignored the organisation. ${ }^{53}$ By early 1974 Colonel Brush formed a working relationship with UDA leader Andy Tyrie and 3 Brigade intelligence reported that a well-known UDA commander in County Down now described DOW as the UDA's "sister organisation". ${ }^{54}$ DOW later joined the UVF and the Red Hand Commando in the Ulster Loyalist Central Coordinating Committee as part of the militant response to the Sunningdale Agreement in December 1973. The agreement established a short-lived power-sharing executive, assembly and included an advisory role for the Irish government in Northern Ireland's affairs. Paramilitary organisations such as the UDA, UVF, USCA and DOW played an important role in mobilising the Ulster Workers' Council strike in May 1974 that collapsed these institutions. ${ }^{55}$

On November 101978 the RUC discovered a Harrison M300 lathe, used for turning gun barrels, at a farm on the Ards Pensinsula in the north of County Down; 14 weapons, 37 magazines and 480 bullets were also seized by the police. Bill Hannigan, who was later described in court as the "the prime party in the offences", was arrested along with William Lightbody, a member of the UVF in north Down and four other men, including the owner of 
the farm, John Steele. Hannigan, Lightbody and Steele were all charged and convicted of illegally manufacturing weapons over a period of more than a year and a half. A former RUC Reserve officer, Samuel McCullough, was also convicted in relation to weapons offences. When police officers searched Hannigan's home near Donaghadee, they found a further eight guns, five magazines, gun parts and 1,017 rounds of assorted ammunition. ${ }^{56}$ Hannigan, who was described as a leading member of DOW at his trial, was given a 16 years sentence for a number of offences, including conspiring to illegally manufacture sub-machine guns; Lightbody was given a total of 12 years for firearms related offences and for membership of the UVF. ${ }^{57}$ During the course of the investigation Hannigan named a senior Belfast UDA commander, who he claimed first approached DOW during the Ulster Worker's Council strike in 1974 to discuss finding a suitable location for the lathe. Hannigan arranged the delivery of the lathe to Steele's farm and subsequently took charge, together with representatives from the UDA and the UVF, of a large-scale arms manufacturing and maintenance operation in the area. William Lightbody and Bill Hannigan also later related how they travelled to Portadown to collect arms from loyalists there. No prosecutions were brought against two prominent UDA commanders named by Hannigan as playing a key role in the affair. ${ }^{58}$

The north Down brigade of the UVF later erected a mural to Hannigan and nine other "fallen comrades" in the town of Newtownards. The next name after Hannigan's is that of William Lightbody. ${ }^{59}$ After Hannigan's conviction, Colonel Brush petitioned unsuccessfully to the Northern Ireland Office (NIO) for "... a Queen's pardon for this old soldier". An irritated Brush later wrote that "... Lord Gowrie replied to me through a secretary that he was unable to help." ${ }^{\prime 0}$ Nevertheless, in the summer of 1980, barely six months after Hannigan's conviction, military headquarters in Northern Ireland organised a party in Brush's honour to celebrate the $60^{\text {th }}$ anniversary since his commissioning as an officer in the British Army. The event was hosted in Lisburn by the Commander Land Forces Northern Ireland, Major General James Glover and the Commander of 39 Brigade, Brigadier David Ramsbotham. ${ }^{61}$ Such an indulgent attitude to DOW's leader was consistent with the security forces' relationship with the paramilitary organisation during the decade or so of its existence. DOW's leaders were almost all ex-British Army and/or UUP. It was essentially treated as a respectable paramilitary organisation. But, as the army and the RUC knew from 1973 onwards, the separation of DOW from the UVF and UDA was far from clear-cut. Not only did Brush work closely with the UDA and UVF leadership, but a senior DOW leader, Bill Hannigan, oversaw the manufacturing of weapons for the UDA and the UVF. DOW may not have carried out its own paramilitary attacks, but its leadership was willing to arm and equip those that did. As will also become evident in the next section on the loyalist campaign across the border in Monaghan and Cavan, paramilitaries cannot function effectively without an armourer - somebody to build and service weapons - and local intelligence.

\section{Loyalist Intelligence and Cross-Border Raids}

\section{Seek and Destroy: Loyalist Operations in County Monaghan}

A sustained loyalist cross-border campaign in County Monaghan in late 1973/early 1974 began with an attack on November 10 on a house just outside the town of Clones in County Monaghan. During the preceding months the security forces had identified a suspected IRA safe house at 'Four Ash Trees' crossroads in the townland of Legnakelly, a mile or so from the border. Intelligence received by the British Army alleged that Noel Thornbury, originally from Lurgan in County Armagh but who now resided in the house, was the Officer Commanding (OC) of the IRA ASU in the Clones area. ${ }^{62}$ Another British intelligence report indicated that a leading member of the IRA Army Council, Dáithí Ó Conaill, regularly met 
with Thornbury at the house in Legnakelly, suggesting its importance as a de facto command centre for the IRA in the area. In late October 1973 British Army intelligence officers reported that Kevin McKenna, then believed to be in command of IRA operations in Fermanagh and Tyrone, may have been staying in the house. He had previously been observed in the vicinity of Legnakelly in May. ${ }^{63}$ MOD officials were concerned that a Garda sergeant in Clones, Paschal McArdle, was deliberately frustrating attempts to arrest McKenna, Thornbury and other senior IRA volunteers in the Clones area. RUC Chief Inspector Harry Currie met with McArdle but found him to be evasive: "McArdle was seen to visit Four Ash Trees frequently but when pressed always replied that there was nothing of interest there." 64

Shortly before midnight on 10 November 1973 a group of eight armed men in two cars crossed the border. They drove to the Thornbury house where, masked and armed, they entered the back door of the house. There they found Noel Thornbury and his wife Stephanie in the kitchen with three unidentified men. Some of the loyalist gunmen went upstairs with Stephanie Thornbury where they searched the bedrooms and told her that her husband would be shot. ${ }^{65}$ Downstairs other members of the group assaulted the four men before planting a bomb with a fuse attached and forcing the men and Stephanie Thornbury outside. ${ }^{66}$ The gunmen told the men that they were going to be shot and directed them to a shed at the back of the house. At this point Noel Thornbury and his companions broke free from their wouldbe executioners and ran in the direction of the fields at the rear of the house. Thornbury was shot in the back and, although badly injured, made it to a neighbours' house belonging to the O'Hart family. The O'Harts called for a doctor and Thornbury ultimately survived following treatment in Monaghan hospital. The other three men in the house also escaped. ${ }^{67}$ Another neighbour, Seán Kinsella, a local republican who lived across the road from the Thornbury house, opened fire on the escaping gunmen as they drove away. The house was completely destroyed in the subsequent explosion. ${ }^{68}$

A few miles west of Clones lies the Drummully salient, an incongruous few square miles of Monaghan that juts into Northern Ireland. The isolation of the area, and its proximity to potential targets in Northern Ireland, meant that the area was particularly favoured by the IRA as a staging post for cross-border raids. British Army intelligence reports in late 1973 pointed to the IRA using several houses in the Drummully area, including a large, unoccupied Georgian manor, Clonoony House. ${ }^{69}$ The relative absence of Gardaí and the Irish Defence Forces, whose principal route into the area is by concession roads in Northern Ireland, was noted by the security forces and loyalists. Both did not remain idle in the face of such a growing IRA threat in Drummully. After a Monaghan republican, Phil McDonald, was arrested and charged with the possession of an unlicensed revolver, his house in the Drummully salient was searched and ransacked..$^{70}$ Gardaí investigating reports of unusual activity in the area discovered RUC Chief Inspector Harry Currie at the McDonald property. According to the Irish government, Currie was "a wanted man in the eyes of the IRA, allegedly for shooting at some civilians”. Des O’Malley, the Irish Minister for Justice, later issued "a friendly warning" to the British ambassador about Currie's conduct, since the Irish government did not want a shooting incident between the RUC and the IRA in the Republic of Ireland..$^{71}$

On 19 December 1973 John Brooke, now $2^{\text {nd }}$ Viscount Brookeborough after the death of his father in August, made a speech in the House of Lords describing how he had recently travelled to see an IRA “camp", just across the border in County Monaghan. There Brooke observed, "... two 'boyos' run back across the border. The house was 50 yards from the 
Border ... We know that this house exists; surely the Dublin Government knows it. In fact, we know they do, because the security forces know it and they have been in touch. ${ }^{72}$ Three days later, on the night of 22 December, a bomb exploded in an unoccupied farmhouse a few yards from thje broder, in Clonrye, a townland in Drummully, County Monaghan. Gardaí later found five rifles, 437 rounds of ammunition, combat gear, face masks, some explosives material and a map of the Newtownbutler area underneath the debris. ${ }^{73}$ A British Army intelligence report on the incident commented that: "There have been previous reports of explosives being present in a derelict house on the EIRE [sic] side of the border. The Gardai [sic] had previously searched every house in the area except the one with the explosives in, hence the explosion on the 22 Dec 73 and subsequent arms find." 74 On 24 December 1973 an Irish Army patrol under the command of Lieutenant Edge went to the scene of the explosion. At the lane leading up to the farm Lt. Edge encountered RUC Chief Inspector Harry Currie in an unmarked car. Both Currie and another plainclothes RUC officer denied that they had come to see the destroyed farmhouse but did not say why they were south of the border. ${ }^{75}$

On 5 January 1974, Phil McDonald's house was burned down. The next day Clonoony House was also targeted and burned to the ground. By now loyalists had successfully targeted four suspected IRA safehouses or staging points in the Clones/Drummully area. On 30 January the Irish Army defused another bomb at a fifth house, also in Clonoony. This bomb marked the end of a three-month period of loyalist operations in the Clones/Drummully area of Monaghan, including the attempted murder of Sinn Féin councillor Frank McCaughey in a bomb attack on his employer's meat processing factory in Clones on 25 January. ${ }^{76}$ The range of reports received by the British Army - and varying grades allocated to informants appear to indicate that intelligence officers had other sources, beyond the Irish police and army, when it came to IRA activity in the Clones area of Monaghan. Former USC and serving UDR officers also had long-established ties with the area. The intelligence officer of the UDR in County Fermanagh, Major Albert Liddle, was a member of Clones Masonic Lodge. Samuel Hutchinson, a former sub-commandant of the USC in the south-east of Fermanagh (not far from Clones) and an Unionist Unity candidate in 1973, had close family ties with Legnakelly; his family owned a farm in the same townland as Noel Thornbury/the Kinsellas and he himself served as a senior member of the Royal Black Preceptory - a traditionally Unionist, loyal institution - in that part of Monaghan. ${ }^{77}$ If the security forces could maintain such ties to Monaghan, so could loyalists who wished to take the war across the border to the IRA. Indeed, UDA representatives claimed that they had set up an intelligence network south of the border to monitor republicans, which was instrumental in a raid on an IRA arms dump near Redhills in County Cavan on the night of 5 October 1972. ${ }^{78}$

For the IRA, loyalist intelligence south of the border appeared to be worryingly accurate (as in the case of Clonrye). Their response was disastrous. Members of the County Monaghan IRA believed that a local Protestant man, George Coulson, was responsible for providing intelligence to loyalists, which led to the attack on the Thornbury house. An IRA raid on the Coulsons' farm near Clones resulted in the burning of the family home and the killing of Billy Fox, a Protestant member of the Irish Senate who was engaged to George Coulson's sister, Marjorie. Four local republicans, including Seán and Michael Kinsella, were later convicted in relation to the attack. Even many IRA sympathisers were appalled by the killing of Fox and the attack on the Coulsons; the incident caused significant "loss of prestige" for the IRA south of the border. ${ }^{79}$ Both Leahy and Mulroe have argued persuasively that the incident led to a more "proactive stance" on the part of the Irish government in countering the IRA, including an increased Garda presence on the border. ${ }^{80}$ Tommy McNulty, who was an IRA volunteer in County Monaghan, later recalled the changed atmosphere: "The next 
morning all hell broke loose in Co. Monaghan. There were Gardaí, Irish army and Special Branch everywhere." Several Monaghan republicans, including McNulty, were charged with IRA membership and jailed in the days in a security sweep after the killing of Billy Fox. ${ }^{81}$

\section{Blowing up Belturbet: Loyalist Operations in County Cavan}

At 1 a.m. on 21 November 1972, a Garda car was on a routine patrol towards Aghalane bridge, which separated County Cavan in the Republic of Ireland from County Fermanagh in Northern Ireland, found that the road was blocked by bales of hay 100 metres from the bridge. On top of the bales was a cardboard sign with the letters 'BOM' [sic]. Seconds after the patrol's arrival there was a large explosion. The $19^{\text {th }}$ century, 40 feet masonry arch bridge over the Woodford canal section of Lough Erne was badly damaged and a number of nearby houses had their windows shattered. The Irish customs hut was also nearly destroyed.

Aghalane was part of a main, approved road linking the towns of Belturbet and Enniskillen in addition to wider regional traffic between the south of Ireland and north-west Ulster. Since early 1972, the area immediately to the north of the bridge had also been the site of a number of IRA ambushes. ${ }^{82}$ Exactly two months earlier, 53 year-old Tom Bullock, a popular local UDR part-time soldier, farmer and caretaker for the Earl of Erne, and his wife Emily were shot dead in their home by a cross-border IRA unit which had travelled the short distance across the Aghalane bridge to the Bullock farm. ${ }^{83}$ The killing of the Bullocks was particularly shocking; outraged unionists demanded a response from the British government including the closing of the bridge. However, the MOD and HQNI struggled to find a solution. They could not unilaterally close the road as it had been confirmed as an "approved" cross-border route five years previously. Only unapproved roads could be cratered and shut. ${ }^{84}$

Captain Vernon Rees, the army officer responsible for security in south-west Fermanagh, believed that he found an answer to the problem of Aghalane Bridge. In an interview for the Imperial War Museum oral history archive, Rees recalled that shortly after the killing of the Bullocks he was introduced by a local RUC chief inspector to Jack Leahy, a 46-year-old publican and auctioneer, who he described as being a leading representative of the UDA in South Fermanagh. In Rees's view, “... anybody who would help me defeat the IRA would be a friend of mine. And that in those days included the UDA." Ultimately, he decided to cooperate with Jack Leahy as a response to the Bullock and other IRA killings. ${ }^{85}$ Leahy was originally from County Cavan; in the early 1950s he moved to Fermanagh, near the Drummully salient. ${ }^{86}$ In 1973 Lord Erne nominated Jack Leahy to successfully stand as an 'Unionist Unity' candidate in the Fermanagh District Council elections (Unionist Unity was an anti-Sunningdale coalition linked to the Vanguard movement) ${ }^{87}$ After Leahy's pub in the South Fermanagh town of Lisnaskea was bombed in 1972 both he and Lord Erne applied for planning permission related to the Wyvern Inn's reconstruction. ${ }^{88}$ Leahy came to believe that, "the less roads you have for people to get in [to Fermanagh] and commit assassinations the better." 89

Captain Rees recalled that he met with Jack Leahy at the Wyvern Inn shortly after the Bullocks' death. By Rees's account, Leahy asked him to ensure that his soldiers were kept outside the area of Aghalane bridge on the night/early morning of 20/21 November. Rees had a moment of uncertainty, "Am I about to cooperate with a terrorist in the Ulster Defence Association in the destruction of a main road in the United Kingdom?"90 Ultimately, Rees agreed to keep his soldiers away from the bridge. However, after the initial explosion on 21 November, he realised that the bridge was not as badly damaged as he had hoped. Rees then ordered a reluctant RAOC bomb disposal non-commissioned officer to carry out a further explosion: 
I said ... 'I'm Captain Rees. I'm very glad you've come out to look at this. There's some very unstable explosives up there and I don't want it moved really. I want you to destroy it on the bridge.' He went up and he came down and he said, 'It's mud.' And I said, 'No, no, it's not mud. It's unstable, homemade explosives.' And he said, 'If I blow that up there, sir, it will blow the central arch down.' And I said, 'If that's what happens, that's what happens.' And he said, 'Are you telling me ... ?' And I said, 'Go up there and clear that thing.' Anyway, he blew it up with about a quarter of a pound of PE [plastic explosives]. Both the arches flew out and the central arch collapsed. Ten minutes later I go up and there is this inspector from the Gardaí who says, 'What have you done?'91

Does Rees's account tally with other evidence? In a draft reply to a question in the House of Lords the NIO offered some revealing information: "On 22 November at $1510 \mathrm{hrs,} \mathrm{a} \mathrm{routine}$ Army patrol visited the scene and found $40 \mathrm{lbs}$ of explosives under the bridge. It was too dangerous to remove and at 1615 it was detonated in situ. The Garda had been notified and were present at the time...."92 The NIO version echoes at least some of the detail given by Rees, even it leaves out the ruse to further damage the bridge.

The British Army's most senior officer in Northern Ireland, Lieutenant General Harry Tuzo, made it clear to the NIO that he was "delighted" that the bridge had been blown up and wanted it to remain closed indefinitely. ${ }^{93}$ But, despite two explosions, the bridge remained substantially intact and Cavan County Council decided to erect a temporary bailey bridge until more permanent repairs could be undertaken. On hearing of these plans, Frank Steele, an NIO official seconded from MI6, asked the British Embassy in Dublin to notify the Irish government that the erection of a bridge without the consent of Fermanagh County Council (then unionist controlled) would be viewed as going against "courtesy and perhaps of law". 94 Nevertheless, the Cavan local authorities proceeded to erect the bailey bridge and the road was reopened on 24 December 1972. John Brooke was outraged, describing the bailey bridge as "an invasion of United Kingdom territory by a foreign power." 95

At approximately 9pm on the night of 28 December a red ford escort with at least two passengers, a young man and a woman, crossed the bailey bridge at Aghalane and made its way to the nearby town of Belturbet in County Cavan. An hour and a half later, the same car exploded on Main Street, Belturbet, killing two teenagers, Geraldine O'Reilly and Paddy Stanley. Twelve more people were injured, some seriously, including Geraldine O'Reilly's brother who was waiting outside the takeaway. Multiple buildings and parked cars were damaged; the town postmaster Leonard McGovern thought, "the whole town had gone up".96 Some residents of the town were in no doubt as to why Belturbet was targeted, viewing it, "... as a reprisal for the opening of Aghalane Bridge ... One man said that he had sat up for ten nights waiting for a bomb." ${ }^{97}$ Clones and Pettigo were also targeted on the same night two men were seriously injured in Clones - but Belturbet suffered the most. A local newspaper, the Fermanagh Herald concluded that local knowledge was vital in the execution of the attack but that explosives experts would have been brought in from outside the county to prepare the bombs..$^{98}$ Garda intelligence and the subsequent Irish judicial report into the bombings thirty years later focused on one suspect, a loyalist paramilitary called Robert Bridge who lived near Enniskillen and was subsequently convicted of a sectarian murder ${ }^{99}$ In recent years a former RUC inspector in Lisnaskea, Paddy McGuinness, recalled that he was concerned about a man who was staying in Bothwell's Hotel (just across the street from the Wyvern Inn) at the time. This man was working on a contract given to a Newtownabbey, 
County Antrim building firm, Laings, to construct a dairy factory in Lisnaskea. McGuinness believed that, at one point the suspect had built a poorly constructed bomb in Lisnaskea towards the end of $1972 .{ }^{100}$

Forty years earlier, in March 1973, the British Army believed that they had identified a leading paramilitary in Fermanagh who they suspected was responsible for "recent bombings" across the border. He was not Robert Bridge, but he was from Newtownabbey. On 13 March William McMurray, Newtownabbey, County Antrim and James Campbell, with addresses in Derrygonnelly, County Fermanagh and Newtownabbey were charged with stealing £312 from a man in Derrygonnelly and the illegal possession of a Walther pistol and ammunition. ${ }^{101}$ Campbell, a native of south Donegal, was a former Northern Irish customs officer. In September 1972 an IRA ASU attacked Campbell's customs post at Belleek, west Fermanagh, ordering Campbell and another colleague out of their hut before planting explosives which completely destroyed the customs building and damaged Campbell's car. ${ }^{102}$ At a court hearing in 1973 Billy McMurray described himself as the Belfast UDA's liaison officer with Fermanagh and Tyrone. ${ }^{103}$

British Army intelligence believed that Billy McMurray was an experienced and senior loyalist paramilitary, identifying him as "OC of a UDA Special 'Commando' Team", from Belfast that was now operating in west Ulster. Another British Army intelligence report stated that McMurray was an associate of Robert Bridge (the latter was described as a lieutenant and possible one-time OC of the Fermanagh/Tyrone UDA). In early 1973 McMurray was clearly regarded by the British Army as a driving force behind loyalist activity in Fermanagh and across the border during the months preceding his arrest in March 1973. ${ }^{104}$ After the robbery at Derrygonnelly, a British Army intelligence report noted that, "Of the two men arrested for robbery at Derrygonnelly, one was a leading member of a UDA Commando type gang from Belfast who were believed responsible for various explosions in Eire [sic]." The report went on to note that, "Local UDA were not, however, a threat." 105 This is a poor assessment of the threat from the Fermanagh UDA during this period. Later that year another British Army intelligence report noted that they believed that Fermanagh members of the Ulster Freedom Fighters (UFF) - a name also used by members of the UDA were suspected of being responsible for the shooting of nationalist MP Frank McManus (the UFF also later claimed that they were behind the attack). ${ }^{106}$

Lieutenant Colonel Anthony Millen, a senior staff officer at HQNI, believed that the Belturbet bombing helped to make the British case to permanently close the Aghalane Bridge, stating that, “ ...these incidents should encourage the Republic's authorities to support our wish to leave the road physically (opposed from legally) closed."107 John Brooke, while extending his sympathy to the victims, also noted that the unilateral reopening of the bridge at Aghalane by Cavan County Council meant that loyalists could just as easily use that route to inflict terror on the people in Cavan as the IRA did when attacking targets in Fermanagh. Brooke hoped that Irish government policy would now change. ${ }^{108}$ In the early morning of 11 January Aghalane bridge was again blown up, rendering it once more unusable. The bomb was powerful enough to rip out the steel girders of the bailey bridge and it was also connected to another device that had been placed in the Irish customs hut. ${ }^{109}$

The Fermanagh nationalist MP John Carron urged the Irish government not to give in to the threat from loyalism. The bridge was a vital economic link; the Irish government should not be bullied: "Defy them to do it again. Let the bridge be restored and give the bomb merchants the message, 'Right, try it again." 110 No further attempt was made to repair the bridge. South 
of the border politicians and businessmen in Cavan and Monaghan sharply criticized security measures in the wake of the loyalist bombings. In Belturbet and Clones vigilante groups were formed; local leaders demanded a much greater Garda presence. Belturbet's Town Commissioners sent a request to the Irish government for a 24-hour presence by the Irish Defence Forces on the remaining nearby border crossing. Locals also urged the Irish security forces to rigorously check vehicles "the same as they were doing in Northern Ireland". Under pressure, the Irish government responded by stepping up its security presence in the border area near Belturbet. There was a significant increase in Irish police and army checks on border crossings in the weeks after the bombings of 28 December. ${ }^{111}$

\section{Conclusion}

This article has shown the impact of rural loyalist mobilization and the resulting border campaign in shaping the conflict in the early Troubles. Loyalist terrorism worked, up to a point. The Irish peer Lord Kilbracken astutely observed in a speech to the House of Lords in 1977 that it was "... remarkable that the destruction of a bridge by terrorist forces should be considered an act which is indispensable for security purposes."112 IRA access to south Fermanagh became more difficult since the Irish authorities did not attempt to reopen Aghalane bridge after January 1973 and increased security on other border crossings. Loyalists targeted a number of suspected IRA safe houses or staging posts in the Drummully salient, eliminating at least one arms dump in the process. The loyalist attack on the Thornbury house at Legnakelly precipitated a series of events that undermined the IRA in County Monaghan, namely the burning of the Coulson home and the killing of Senator Billy Fox, which prompted the Irish government to increase security operations in Monaghan. IRA activity in the Clones area never recovered to the levels seen before 1974. By 1975 the British government noted that the IRA had suffered "considerable attrition" in the border region at the hands of the Irish state. ${ }^{113}$

Tactical gains against the IRA must, however, be weighed up against the lasting damage to the reputation of the British state as a result of the loyalist border campaign. Suspicions over the links between the security forces and attacks by loyalist paramilitaries diverted attention away from IRA atrocities such as the murders of the Bullocks. A local newspaper, the Fermanagh Herald summed up the response of the nationalist community, "People are not fools. They see Unionist terrorists doing pretty well what they please. Until the British Army takes stern and decisive action against the military organisations of the Unionists it may forget completely about being accepted as a reputable security force..." 114 Republican sympathies, or at least a pronounced sense of grievance and resentment of the British state, endured in Cavan and Monaghan, contributing to the election of IRA Volunteer and hungerstriker Kieran Doherty to the Irish parliament's lower house, Dáil Éireann in 1981. ${ }^{115}$ There is considerable potential for further work on loyalist networks in rural Ulster, including loyalism's complex relationship with the state, intelligence and the exchange of violence with the IRA. The capacity for agency among low or mid-ranking representatives of the state, as evidenced in the account of Captain Rees, suggests that the study of deviance could be a fruitful means of investigating collusion in Northern Ireland and elsewhere.

Since the British Army and the RUC were competing with the IRA for influence and information within the Catholic population, the suspicion among nationalists that the security forces were unresponsive to, and possibly even facilitating, loyalist paramilitary violence can only have damaged the state's objective of winning trust. Such misgivings have, to some extent, been corroborated in this article. The British Army had valuable intelligence on a UDA 'commando' unit which it believed was responsible for bombings in the Republic of 
Ireland. Neither the British Army nor the RUC appear to have passed this information to the Irish police investigation into murders at Belturbet. Moreover, the security forces' attitude towards the activities of DOW / representatives of the UUP involved in paramilitary activity was indulgent and inept. Personal contacts and institutional relationships between serving members of the security forces with their former comrades, such as Peter Brush and Bill Hannigan, were confused for assurances of good behavior. More questions should have been asked about whether British intelligence was being leaked to loyalists; as seen in the evidence presented here, the timings of 3 Brigade intelligence findings and subsequent loyalist operations could be alarmingly close. Instead of being angered by successive bombings at Aghalane and Belturbet, some British officials believed that such attacks were to the government's advantage. At a junior level, in the case of Aghalane Bridge, there is significant evidence of direct collusion between the British Army and loyalist paramilitaries. Eventually a number of loyalists who were operating in rural areas, including Robert Bridge and Bill Hannigan, were arrested and convicted. But, to some extent, it was too late. The reputation of the British state had been badly damaged by a tardy and incoherent response to loyalist terrorism along the border.

1 "Report from OC 3 Inf. Coy Group to Comd. Intelligence Offr.", Western Command, January 17 1972, 2004/15/81, Military Archives of Ireland, Dublin [hereafter MAI].

2 Impartial Reporter [County Fermanagh Newspaper], March 91972.

${ }^{3}$ Impartial Reporter, November 3 1972; and Impartial Reporter, November 91972.

${ }^{4}$ Impartial Reporter, November 3 1972; and Impartial Reporter, November 91972.

${ }^{5}$ Anthony Craig, A Crisis of Confidence: Anglo-Irish Relations in the Early Troubles, 19661974 (Dublin: Irish Academic Press, 2010), 186.

${ }^{6}$ Shaun McDaid, Template for Peace: Northern Ireland, 1972-1975 (Manchester:

Manchester University Press, 2013), 154-181.

${ }^{7}$ Thomas Leahy, "Informers, Agents, the IRA and British Counter-Insurgency Strategy during the Northern Ireland Troubles, 1969 to 1998" (PhD Thesis, King's College London, 2015), 184-185.

8 Patrick Mulroe, Bomb's Bullets and the Border (Dublin: Irish Academic Press, 2019), 227228.

${ }^{9}$ Ibid.

${ }^{10}$ Richard English, Does Terrorism Work? (Oxford: Oxford University Press, 2016), 9-12.

${ }^{11}$ Ibid.

12 "Robert Simpson: Representations against Internment Order.", HA/5/962B, Public Record

Office of Northern Ireland [hereafter PRONI].

${ }^{13}$ Richard English, Terrorism: How to Respond (Oxford: Oxford University Press, 2009), 24.

${ }^{14}$ Brian Hanley, The Impact of the Troubles in the Republic of Ireland (Manchester:

Manchester University Press, 2018).

${ }^{15}$ Henry Patterson, Ireland's Violent Frontier (London: Palgrave Macmillan, 2016).

${ }^{16}$ See, for example, Anne Cadwallader, Lethal Allies (Cork: Mercier Press, 2013); and

Margaret Urwin, A State in Denial (Cork: Mercier Press, 2016).

${ }^{17}$ Amy Grubb, "Microlevel Dynamics of Violence: Explaining Variation in Violence among

Rural Districts during Northern Ireland's Troubles," Security Studies 25, no. 3 (2016): 464. 
18 Steve Bruce, The Red Hand: Protestant Paramilitaries in Northern Ireland (Oxford: Oxford University Press, 1992), 15.

${ }^{19}$ Richard Reed, Paramilitary Loyalism: Identity and Change (Manchester: Manchester University Press, 2015); James McAuley, The Politics of Identity: A Loyalist Community in Belfast (Amersham: Avebury Press, 1994); and Bruce, (see note 9 above).

${ }^{20}$ Grubb, (See note 8 above), 464.

${ }^{21}$ Stathis Kalyvas, "The Urban Bias in Research on Civil Wars," Security Studies 13, no. 3 (2004), 160-190.

22 Jim Cusack and Henry McDonald, UVF (Dublin: Poolbeg Press, 1997), 271.

${ }^{23}$ Mark McGovern, Counterinsurgency and Collusion in Northern Ireland (London: Pluto, 2019), 4.

${ }^{24}$ Edward Burke, An Army of Tribes: British Army Cohesion, Deviancy and Murder in Northern Ireland (Liverpool: Liverpool University Press, 2018), 12.

${ }^{25}$ For a description of CESA see, James Hughes, 'State Violence in the Origins of Nationalism: British Counterinsurgency and the Rebirth of Irish Nationalism', in John Hall and Sinisa Malesevic, Nationalism and War (Cambridge: Cambridge University Press, 2013), 112.

26 "Shooting Statistics for the period 1971-1977", CJ 4/1764, The National Archives, London [hereafter TNA].

27 "Intelligence Summary No. 11/72 for the period 9 May-16 May 1972": 3 Brigade, WO 305/4209, TNA.

28 "Intelligence Summary No. 32/73 for the period 6 August-13 August 1973," 3 Brigade, WO 305/4216, TNA.

${ }^{29}$ Impartial Reporter, October 121972.

${ }^{30}$ Impartial Reporter, March 161972.

${ }^{31}$ Impartial Reporter, August 241972.

${ }^{32}$ Impartial Reporter, July 201972.

33 Impartial Reporter, October 26 1972; and Impartial Reporter, November 231972.

${ }^{34}$ Impartial Reporter, October 121972.

35 "Letter from R.A. Custis, Ministry of Defence to R.T. Armstrong, Prime Minister's Office, 17 March 1972," FCO 87/31, TNA; "3 Infantry Brigade Intelligence Summary No. 30/73 for the period 23 July - 30 July 1973", 3 Brigade, WO 305/4215, TNA.

36 "RUC/Army/UDR Coordination", Memo by Brigadier Peter Bush, January 16 1973, WO 305/4210, TNA.

37 Ibid.

38 "Directive on Security Forces Reactions to Protestant Activity", 3 Infantry Brigade, June 17 1972, WO 305/4209, TNA.

39 "Intelligence Summary No. 44/73 for the period 29 October 1973 - 5 November 1973", 3 Brigade, WO 305/4219, TNA.

${ }^{40}$ Belfast Telegraph, February 221978

${ }^{41}$ Irish Times, November 41973

42 Belfast Telegraph, June 15 1970; and Impartial Reporter, April 191974.

${ }^{43}$ Lieutenant Colonel Edward James Augustus Howard 'Peter' Brush, "Rifle Green, Orange Flash", Unpublished Memoir [circa early 1980s], Private Papers of Lieutenant Colonel EJAH Brush, Document 3525) Imperial War Museum, London.

${ }^{44}$ Ibid, 167.

${ }^{45}$ Court file of John Steele, William John Hannigan, William Lightbody, Samuel Wallace McCullough, James Steele, William Robert Steele, 1978-1979, CRCT/3/2/1/316, PRONI. 46 Ibid. 
47 “Intelligence Summary No. 48/73 for the period 26 November - 3 December 1973," 3 Brigade, WO/4220, TNA.

48 The UDA was the other organisation mentioned as being possibly the owner (or the intended customer) of the weapons. "Intelligence Summary No. 39/73 for the period 24 September - 1 October 1973", October 1973, WO 305/4218, TNA.

49 "Intelligence Summary No. 15/73 for the period 9 April - 16 April 1973", 3 Brigade, WO 305/4212, TNA; "Intelligence Summary No. 34/73 for the period 20 August - 27 August 1973," 3 Brigade, WO 305/4216, TNA.

50 "Intelligence Summary No. 33/73 for the period 13 August - 20 August 1973," 3 Brigade, WO 305/4216, TNA.

51 "Intelligence Summary No. 27/73 for the period 10 July - 17 July 1973," 3 Brigade, 305/4215, TNA.

52 "Intelligence Summary No. 48/73 for the period 26 November - 3 December 1973" (See note 38 above).

53 "Intelligence Summary No. 41/73 for the period 8 October - 15 October 1973", 3 Brigade HQ, October 1973, WO 305/4218, TNA.

${ }^{54}$ Belfast Telegraph May 28 1980; "Infantry Intelligence Summary No. 34/73 for the period 20 August - 27 August 1973," 3 Brigade, WO 305/4216, TNA.

55 Belfast Telegraph, May 251976.

${ }^{56}$ Belfast Telegraph, October 271979.

57 Ibid.

${ }^{58}$ Court file (see note 36 above).

${ }^{59}$ See Jonathan McCormick, "A Directory of Murals - Album 5", CAIN, last modified June 2 2019, accessed December 16 2019, https://cain.ulster.ac.uk/mccormick/album51.htm

${ }^{60}$ Brush (see note 34 above), 22.

${ }^{61}$ Brush (see note 34 above), 222.

62 "Headquarters 3 Infantry Intelligence Summary No. 41/73 for the period 8 October -15 October 1973", 3 Brigade, WO 305/4218, TNA.

63 "Intelligence Summary No. 43/73 for the period 22 October - 29 October", 3 Brigade, WO $305 / 4218$, TNA.

64 Telegram from HQNI, November 16 1973, published by Broken Elbow, accessed

November 9 2019, https://thebrokenelbow.com/2014/02/06/the-british-armys-war-with-

garda-sgt-mcardle-a-collusion-controversy-from-the-1970s/

${ }^{65}$ Northern Standard, November 161973.

${ }^{66}$ Anglo-Celt, November 161973.

${ }^{67}$ Northern Standard, November 161973.

${ }^{68}$ Magill, October 11984.

69 "Intelligence Summary No. 48/73 for the period 26 November - 3 December" (see note 38 above).

${ }^{70}$ Northern Standard, April 71972.

71 “Telegram from Sir John Peck to Sir Frank Steele," April 28 1972, FCO 87/119, TNA.

72 Hansard, 348 No. 425, December 191973 (London: HM Stationary Office, 1973).

73 "Sabotage Attempts in Republic of Ireland 18/5/73-28/12/73," 2004/16/82, MAI.

74 "Intelligence Summary, 21 December to 31 December 1973," 3 Brigade, WO 305/4220, TNA.

75 "Sabotage Attempts in Republic of Ireland 18/5/73-28/12/73", (see note 64 above).

${ }^{76}$ Northern Standard, February 11974.

77 Impartial Reporter, August 11994.

${ }^{78}$ Belfast Telegraph, October 61972. 
${ }^{79}$ Mulroe, (See Note 3 above), 157.

${ }^{80}$ Leahy, (See Note 3 above), 92; Mulroe, (See note 3 above), 157.

81 Thomas Anthony McNulty, Exiled (Dublin: Brunswick Press, 2013), 112-13.

82 Anglo-Celt, November 241972.

83 Ibid.

84 "Telegram: Aghalane Bridge," October 4 1972, FCO 87/120, TNA.

${ }^{85}$ Recording of Major Vernon Rees, OC Alkmaar Troop, A Battery (Chestnut Troop), 1st Regiment, Royal Horse Artillery, Sound Archive (Acquisition Number, 27067), Imperial War Museum, London, accessed March 282019.

${ }^{86}$ David Leahy, A History of the Cavan Leahys Volume 2 (Bristol: David Leahy, 2018); 247248.

${ }^{87}$ Fermanagh Herald, May 121973.

88 "Minutes - Meeting of the Planning Committee of Fermanagh County Council", December 6 1972, D3004/C/5/22, PRONI.

89 'The Border', BBC Spotlight, (1974: BBC), BBC Archives, accessed December 162019.

${ }^{90}$ Recording of Major Vernon Rees (see note 76 above).

${ }^{91}$ Rees, (see note 76 above).

${ }^{92}$ Letter from J T A Howard-Drake to J T Williams, December 20 1972, CAB 9N/52, PRONI.

${ }^{93}$ Letter from GOC to Harold Black, Office of the Secretary of State, December 281972 , CAB 9N/52, PRONI.

${ }_{94}$ Memo by Harold Black, December 19 1972, CAB 9N/52, PRONI.

${ }^{95}$ Impartial Reporter, December 211972.

${ }^{96}$ Anglo-Celt, January 51973.

97 Ibid.

${ }^{98}$ Fermanagh Herald, January 31973.

${ }^{99}$ While singling out, and even naming, Robert Bridges [sic] as being a lead suspect in the cross-border bombings of 28 December 1972, the Barron report did point to other suspects, including two customs officers at Belleek, County Fermanagh, who Gardaí believed may have been involved in a later bombing on September 281973 (perhaps not coincidentally 28 September is Ulster Day). Oireachtas Debates, January 27 2005, https://www.oireachtas.ie/en/debates/debate/joint_committee on justice_equality defence_a nd womens rights/2005-01-27/2/, accessed December 162019.

${ }^{100}$ PSNI HET Report Concerning the Murder of Louis Alphonsus Leonard (copy in the author's possession - I am grateful to the Leonard family for making this available), 39;

Belfast Telegraph, June 231975.

${ }^{101}$ Belfast Telegraph, May 181973.

102 Impartial Reporter, September 231972.

103 Belfast Telegraph, May 171973.

104 "Intelligence Summary No. 40/73 for the period 1 October -8 October 1973," 3 Brigade, WO 305/4218, TNA; "Intelligence Summary No. 14/73 for the period 2 April to 9 April 1973," 3 Brigade, WO 305/4212, TNA.

105 "Minutes of the Western Security Committee Meeting", March 29 1973, 3 Brigade, WO 305/4212, TNA.

106 "Intelligence Summary No. 40/73 for the period 1 October -8 October 1973", 3 Brigade, WO 305/4218, TNA; and Fermanagh Herald, September 22 1973;

${ }^{107}$ Letter from Lieutenant Colonel Anthony Millen to S C Jackson, NIO, January 1 1973, CAB 9N/52, PRONI.

108 Fermanagh Herald, January 3 1973; and Anglo-Celt, January 51973. 
109 Fermanagh Herald, January 291973.

110 Ibid.

111 Anglo-Celt, January 51973.

112 Hansard, 387 No. 1022, 24 November 1977 (London: HM Stationary Office, 1977).

${ }_{113}$ Mulroe, (See note 3 above), 157.

${ }^{114}$ Fermanagh Herald, April 61974.

${ }^{115}$ Irish News, August 92019. 